\title{
Utilization of Solar Energy for Air Conditioning System
}

\author{
Juwari Purwo Sutikno ${ }^{1, *}$, Serlya Aldina ${ }^{1}$, Novita Sari ${ }^{1}$, and Renanto Handogo ${ }^{1}$ \\ ${ }^{1}$ Chemical Engineering Departement, Institut Teknologi Sepuluh Nopember, Surabaya, 60111
}

\begin{abstract}
The purposes of this research are to do a system simulation of air conditioning utilizing solar energy with single effect absorption refrigeration method, analyze the coefficient of performance (COP) for each absorbent-refrigerant variable and compare the effectivity of every absorbent-refrigerant variable used. COP is a constant that denotes the effeciency of a refrigeration system, that is ratio of work or useful output to the amount of work or energy input. The higher the number of COP, the more efficient the system is. Absorbent-refrigerant (working fluids) variables used in this research depend on its chemical and thermodynamics properties. Steps in this research are including data collection and tabulation from literature and do a simulation of air conditioning system both commercial air conditioning system (using electrical energy) and solar energy air conditioning system with Aspen Plus software. Next, run the simulation for each working fluid variables used and calculate the COP for each variable. Subsequently, analyze and compare the effectivity of all variables used from COP value and economical point of view with commercial air conditioning system. From the result of the simulation, can be concluded that solar air conditioning can achieve $98,85 \%$ of energy savings than commercial air conditioning. Furthermore, from the calculation of COP, the highest COP value is achieved by solar conditioning system with $\mathrm{LiNO}_{3}-\mathrm{NH}_{3}$ as working fluid where $55 \%$ of the composition is the refrigerant and $45 \%$ of absorbent.
\end{abstract}

\section{Background}

Air Conditioner (AC) is now a sophisticated solution to cope with hot room temperatures, especially in urban areas. Almost all offices, schools or homes in the city can not be separated from the use of air conditioner.

However, adding an energy load to an AC installation will also accelerate global warming and greenhouse effects. Two-thirds of the total energy is used for buildings, where $30-50 \%$ of electricity consumption in buildings is dominated by air conditioning systems.

The negative effects of this increase in energy consumption include:

1. The increasing demand of air-conditioning systems will lead to increased consumption of electricity that will be associated with greenhouse gas emissions.

2. In addition, electrical vapor compression air cooling technology uses $\mathrm{CFC}$ and $\mathrm{HCFC}$ as pollution-causing refrigerants.

Therefore, the existence of alternative technologies capable of creating air conditioning systems without the use of electricity is very important.

Solar air conditioning is a solar energy-based cooling system. Solar energy can be used as an energy source in air conditioning systems in two ways. First, solar energy can be converted into electricity by using photovoltaic cells which are then used to operate vapor compression air conditioning system. Secondly, solar energy can be used to heat the working fluid and regenerate refrigerant in the generator of the vapor sorption (absorption or adsorption) system of air conditioning.

Corresponding author: joecheits@yahoo.com
The application of solar energy to air conditioning systems has several advantages, in addition to offering solutions of negative impacts that have been described earlier, this technology has the advantage:

1. The maximum cooling load is equal to the maximum available radiation

2. The working fluids used are harmless, such as water and salt solution

Current technologies for the production of air conditioners using thermal energy are: absorption chiller, liquid-solid desiccant, and solid adsorption.

\subsection{Previous Research}

Some research on the development of solar-powered air conditioning system has been done. Here is a brief description of previous studies :

$\mathrm{Li}$ and Sumathy [1], presented the results of solarpowered air conditioning systems. The system uses a flat plate collector array with a cooling capacity of $4.7 \mathrm{~kW}$. The system is also equipped with two hot water storage tanks. The value of SCR obtained is 0.07 . The results of the research indicate that in cloudy weather, the system cannot operate in a commonly used.

Syed et al [2], reported the performance of a single effect $\mathrm{LiBr}+$ water absorption refrigeration with a nominal cooling capacity of $35 \mathrm{~kW}$ powered by hot water from $49.9 \mathrm{~m}^{2}$ flat plate collector and $2 \mathrm{~m}^{3}$ hot water tank during the day. SCR value ranges from 0.11. Maximum 
cooling capacity of $7.5 \mathrm{~kW}$ (21\% of nominal) and COP of 0.34-0.42.

Zambrano et al. [3], presented the results of a $\mathrm{LiBr}+$ water single effect absorption chiller with a nominal cooling capacity of $35 \mathrm{~kW}$ powered by hot water from a $151 \mathrm{~m}^{2}$ flat plate collector and equipped with an auxiliary gas fired burner and a $2.5 \mathrm{~m}^{3}$ container tank. Auxiliary gas fired burners are utilized to support the heat of solar radiation when solar radiation heat is not sufficient to drive the system. SCR values obtained by 0.15 and SHF vary from 0.1 to 1 depending on the position of the sun.

\subsection{Solar Thermal Collector}

One important component of solar air conditioning system is solar thermal collector. According to research conducted by Ariane Rosario [4], the total energy received by solar thermal collector per-day can be formulated as follows:

$$
\mathrm{E}=2 I E_{0}\left[\left(\cos (\varphi) \cos (\delta)\left[\frac{\sin (0.2618 \tau)}{0.2618}\right]\right)+(\sin (\varphi) \sin (\delta) \tau)\right]
$$

Indonesia is one of the tropical countries that have the potential to develop solar thermal energy, including the city of Surabaya. Geographically Surabaya is located at 7.24917 south latitude (806 $\mathrm{km}$ from the equator line) and 112.75083 east longitude. If the type of solar thermal collector used is a flat plate collector with $80 \%$ efficiency [5] with operating time for 10 hours $(07.00$ to $17.00)$ then the average energy produced by solar thermal collector will be $528.4 \mathrm{~W} / \mathrm{m}^{2}$.

\section{Methodology}

In this study, there are two models of refrigeration system used, there are vapor compression air conditioning for commercial air conditioning and absorption-refrigeration air conditioning for solar air conditioning.

The first step is collecting the required data. The purpose of this step is to achieve a good simulation result approaching to the actual condition. One of the required data is the air temperature of Surabaya. This data will be used to determine the indoor air temperature to be cooled. The data of the air temperature of Surabaya over the year is presented on the table 1 .

Table 1. The average of the Surabaya air temperature over the year

\begin{tabular}{|l|c|c|c|c|c|c|c|c|c|c|c|c|}
\hline Month & Jan & Feb & Mar & Apr & May & Jun & Jul & Aug & Sep & Oct & Nov & Dec \\
\hline T $\left({ }^{\circ} \mathrm{C}\right)$ & 33,9 & 33,0 & 34,4 & 33,6 & 34,3 & 33,4 & 33,1 & 33,2 & 33,9 & 33,4 & 33,6 & 32,5 \\
\hline
\end{tabular}

Based on the data, the average of air temperature is $33,5^{\circ} \mathrm{C}$.

The next step is simulation process. This step include process modelling and running model by Aspen plus. In this study 4 types of working fluid with 3 different composition as a variable is used. The four working fluids are $\mathrm{LiBr}-\mathrm{H} 2 \mathrm{O}, \mathrm{LiNO} 3-\mathrm{NH} 3, \mathrm{H} 2 \mathrm{O}-\mathrm{NH} 3$, and
NMP-R32 with a ratio of absorbance and refrigerant composition of $45 \%: 55 \%, 50 \%: 50 \%$ and $55: 45 \%$.

The last step is analyse the economic and COP for the each model. COP and economic analysis are the important factors that must be taken into account in determining whether solar air conditioning is feasible to be used or not.

\section{Vapor Compression Air Conditioning}

Commercial air-conditioning systems generally use vapor compression cooling systems. Here is a block diagram of the vapor compression cooling system.

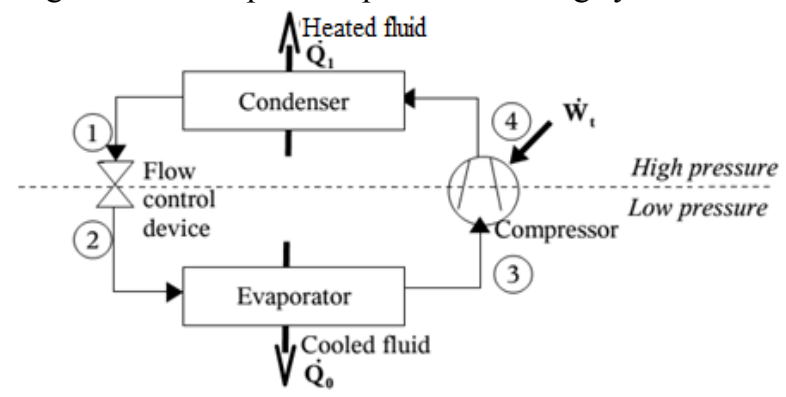

Fig. 1. Block Diagram of Vapor Compression Cooling System

The vapor compression refrigeration system consists of four main processes: compression, condensation, expansion and evaporation [6].

The first stage of the simulation process is the selection of the thermodynamic model to be used. In this study thermodynamic model Peng-Robinson Equation of State selected. This model was chosen because it can be applied over a wide range of conditions, i.e. for temperatures greater than $-271^{\circ} \mathrm{C}$ and pressures of less than $100,000 \mathrm{kPa}[7]$.

In this study, it is selected R-22 refrigerant as working fluid for commercial air-conditioning system. This is because most commercial air conditioners use the R-22 refrigerant as its working fluid [8].

After that, done the modelling using the process blocks that exist in Aspen Plus software. The following is the result of the simulation :

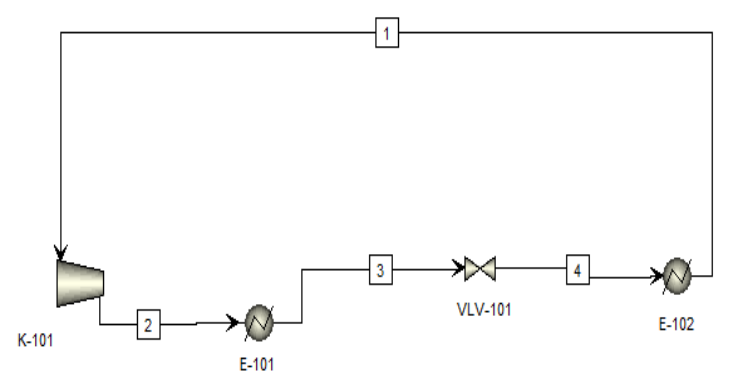

Fig. 2. Vapor Compression Air Conditioning System Block Processing by Using Aspen Plus Software

The first process block is a compressor (K-101). This process aims to increase the pressure of working fluids and circulate them. Flow (1) is a R22 refrigerant with a vapor phase with a mass of $34 \mathrm{~kg} / \mathrm{h}$ and a charge of 72.327 psig. This pressure is adjusted to the standard R22 vapor compression air conditioner, where Standard 
Freon R22 AC commercial pressure is 57.6 psig up to 84.1 psig. For the K-101 (compressor) block the power value is set at 400 watts. This is according to the standard AC $1 / 2 \mathrm{PK}$, where the electric power of the compressor is 320 watts up to 400 watts.

The second process block is a condenser (E-101). In this study the condenser is modelled by using heat exchanger with outdoor air as cooling media. At this stage there is a process of cooling the hot refrigerant vapor from the compressor by air to the condensation temperature, then the vapor is condensed.

The next process block is the expansion process. In this study the expansion process is modelled with a valve (VLV-101). The process of expansion takes place from stream (3) to stream (4). In the process, there is a decrease of the refrigerant pressure from the condensation pressure to the evaporation pressure. When the liquid is expanded through the valve to the evaporator, the refrigerant temperature also drops from the condensate temperature to the evaporative temperature. This process is an adiabatic process, in which the fluid enthalpy does not change throughout the process. The refrigerant in stream (4) is in a mixed of vapor and liquid state.

The final process block is the evaporation process that occurs in the evaporator and takes place at a constant pressure. In this research the evaporation process is modelled by heater. The refrigerant at stream (1) coming out from the evaporator in a saturated vapor state. During this evaporation process occurs, there is absorption of heat from the room that will be cooled. The amount of heat absorbed is set at $5000 \mathrm{Btu} /$ hour.

From the simulation results then calculated the energy requirements for vapor compression air conditioning with a cooling capacity of $5000 \mathrm{Btu} /$ hour. The required energy comes from the compressor's electric power requirement of $0.4 \mathrm{~kW}$.

\section{Solar Air Conditioning}

Solar air conditioning is a solar energy based air conditioner. Solar thermal energy can be used as an energy source in air conditioning systems in two ways. First, solar energy can be converted into electricity by using photovoltaic cells which are then used to operate the vapor compression air conditioning system. Secondly, solar energy can be used to heat the working fluid and regenerate the refrigerant in the generator of the sorption vapor system (absorption or adsorption) of air conditioning [9].

In this study cooling absorption-refrigerant solar air conditioning system is selected. The absorptionrefrigerant air conditioning cooling system consists of five main process units, they are solution pump, generator, condenser, evaporator and absorber [8]. Here is a block diagram of the absorption-refrigerant air conditioning cooling system:

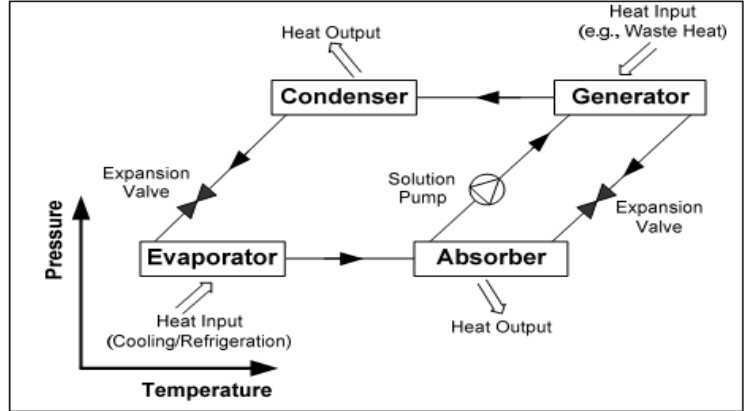

Fig. 3. Block Diagram of Absorption-Refrigerant Air Conditioning System

In this study 4 types of working fluid with 3 different composition as a variable is used. The four working fluids are $\mathrm{LiBr}-\mathrm{H} 2 \mathrm{O}$, LiNO3-NH3, H2O-NH3, and NMP-R32 with a ratio of absorbance and refrigerant composition of $45 \%: 55 \%, 50 \%: 50 \%$ and $55: 45 \%$.

The first stage of the simulation process is the selection of thermodynamic models to be used. For simulations using working fluids $\mathrm{LiBr}-\mathrm{H} 2 \mathrm{O}$ and LiNO3NH3 using ELECNRTL thermodynamic model. This model is used because it is specifically designed for electrolytic solutions such as $\mathrm{LiBr}-\mathrm{H} 2 \mathrm{O}$ [10]. In contrast with $\mathrm{LiBr}-\mathrm{H} 2 \mathrm{O}$ and LiNO3-NH3, the ELECNRTL thermodynamic model is not suitable for $\mathrm{H} 2 \mathrm{O}-\mathrm{NH} 3$ and NMP-R32. Therefore, a different thermodynamic model is chosen. Since there is no specific thermodynamic model for this type of working fluid, a common thermodynamic model is used. The exact thermodynamic model is Peng-Robinson [10].

After that, the modelling using the process blocks that exist in Aspen Plus software is done. The following is the result of the modelling:

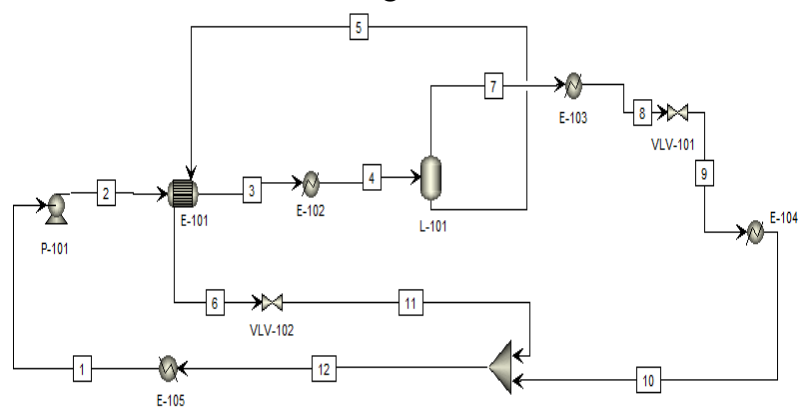

Fig. 4. Absorption-Refrigeration Air Conditioning System Simulation Model Using Aspen Plus V8.8 Software

From the simulation results then calculated the energy requirements for solar air conditioning system with a cooling capacity of $5000 \mathrm{Btu} /$ hour. The energy required comes from the need for electric power of the pump and the energy produced by the solar thermal collector. Here are the details of energy requirements for solar air conditioning systems. 
Table 2. Details of Solar Air Conditioning Energy Requirements

\begin{tabular}{|c|c|c|c|c|c|}
\hline \multirow[b]{2}{*}{ Fluid } & \multirow[b]{2}{*}{ Ratio } & \multirow{2}{*}{$\begin{array}{l}\text { Cooling } \\
\text { load } \\
(\mathrm{kW})\end{array}$} & \multicolumn{3}{|c|}{ Energy Required (kW) } \\
\hline & & & Pump & $\begin{array}{c}\text { Solar } \\
\text { Thermal } \\
\text { Collector }\end{array}$ & Total \\
\hline \multirow{3}{*}{$\begin{array}{l}\mathrm{H}_{2} \mathrm{O} / \\
\mathrm{LiBr}\end{array}$} & $45 / 55$ & 1,465 & $1,54 \mathrm{E}-05$ & 1,810 & 1,810 \\
\hline & $50 / 50$ & 1,465 & $1,35 \mathrm{E}-05$ & 1,800 & 1,800 \\
\hline & $55 / 45$ & 1,465 & $1,20 \mathrm{E}-05$ & 1,794 & 1,794 \\
\hline \multirow{3}{*}{$\begin{array}{c}\mathrm{NH}_{3} / \\
\mathrm{H}_{2} \mathrm{O}\end{array}$} & $45 / 55$ & 1,465 & 0,005 & 1,958 & 1,963 \\
\hline & $50 / 50$ & 1,465 & 0,002 & 1,885 & 1,887 \\
\hline & $55 / 45$ & 1,465 & 0,001 & 1,849 & 1,851 \\
\hline \multirow{3}{*}{$\begin{array}{c}\mathrm{NH}_{3} / \\
\mathrm{LiNO}_{3}\end{array}$} & $45 / 55$ & 1,465 & 0,006 & 1,790 & 1,796 \\
\hline & $50 / 50$ & 1,465 & 0,005 & 1,781 & 1,786 \\
\hline & $55 / 45$ & 1,465 & 0,004 & 1,774 & 1,778 \\
\hline \multirow{3}{*}{$\begin{array}{l}\text { R32/ } \\
\text { NMP }\end{array}$} & $45 / 55$ & 1,465 & 0,026 & 1,945 & 1,971 \\
\hline & $50 / 50$ & 1,465 & 0,020 & 1,948 & 1,968 \\
\hline & $55 / 45$ & 1,465 & 0,016 & 1,909 & 1,925 \\
\hline
\end{tabular}

From the simulation shows that the least energy requirement when working fluid used is LiNO3 / NH3 with a ratio of $55 \%$ refrigerant and $45 \%$ absorbance.

\section{Coefficient of Performance Analysis}

The performance of the cooling system is generally measured by the value of coefficient of performance (COP). Coefficient of performance (COP) is the ratio between the cooling capacity (per unit of energy required) ${ }^{[11]}$. The higher the coefficient of performance (COP) the more effective the cooling system is. Coefficient of performance (COP) can be formulated based on the following equation [11]:

$$
\text { Coefficient of Performance }(\mathrm{COP})=\frac{Q_{C}}{W}
$$

The absorption refrigerant system is a Carnot cycle, so as a parameter of system effectiveness Carnot COP can be calculated based on the following equation:

$$
C O P_{\text {carnot }}=\frac{T o}{T c-T o} \frac{T_{H}-T c}{T_{H}}
$$

Where $\mathrm{T}$ is in Kelvin

Table 3. COP Calculation Result for Vapor Compression Air Conditioning System

\begin{tabular}{|c|c|}
\hline $\begin{array}{c}\text { Working } \\
\text { fluid }\end{array}$ & COP \\
\hline $\mathrm{R}-22$ & 3,663 \\
\hline
\end{tabular}

Table 4. COP Calculation Result for Solar Air Conditioning System

\begin{tabular}{|c|c|c|c|}
\hline $\begin{array}{c}\text { Working } \\
\text { fluid }\end{array}$ & Ratio & COP & COP $_{\text {carnot }}$ \\
\hline \multirow{3}{*}{$\mathrm{H}_{2} \mathrm{O} / \mathrm{LiBr}$} & $45 / 55$ & 0,809 & 1,25 \\
\cline { 2 - 4 } & $50 / 50$ & 0,814 & 1,25 \\
\cline { 2 - 4 } & $55 / 45$ & 0,817 & 1,25 \\
\hline \multirow{3}{*}{$\mathrm{NH}_{3} / \mathrm{H}_{2} \mathrm{O}$} & $45 / 55$ & 0,746 & 3,51 \\
\cline { 2 - 4 } & $50 / 50$ & 0,776 & 3,90 \\
\cline { 2 - 4 } & $55 / 45$ & 0,792 & 3,92 \\
\hline \multirow{3}{*}{$\mathrm{NH}_{3} / \mathrm{LiNO}_{3}$} & $45 / 55$ & 0,815 & 1,27 \\
\cline { 2 - 4 } & $50 / 50$ & 0,820 & 1,28 \\
\cline { 2 - 4 } & $55 / 45$ & 0,824 & 1,28 \\
\hline \multirow{3}{*}{$\mathrm{R} 32 / \mathrm{NMP}$} & $45 / 55$ & 0,743 & 5,21 \\
\cline { 2 - 4 } & $50 / 50$ & 0,744 & 5,24 \\
\cline { 2 - 4 } & $55 / 45$ & 0,761 & 5,24 \\
\hline
\end{tabular}

Based on the above result, the COP value for vapor compression air conditioning cooling system with a cooling capacity of $5000 \mathrm{Btu} /$ hour is 3.663 , while the value of coefficient of performance (COP) for solar air conditioning with the same cooling capacity ranges from 0.743 to 0.824 . Based on these data, it shows that vapor compression refrigeration systems have a higher COP. This is in accordance with the literature which states that the absorption refrigeration system has a range of COP of 0.5 to 1.5 , while the vapor compression system has a value of COP more than 3 . Although the value of COP absorption refrigeration system lower than vapor compression system, this system is still widely used because this system can be used in low-temperature heat utility $\left(<100^{\circ} \mathrm{C}\right)$. In this study, COP for solar air conditioning system cannot be compared with commercial air-conditioning system, because the energy input for solar air conditioning system is obtained free of charge [10]. Therefore, to compare the two systems is done by the calculation of electrical energy savings that can be achieved.

From the results of the COP obtained, for a system with working fluid $\mathrm{LiBr} / \mathrm{H} 2 \mathrm{O}$ the COP value is 0.809 0.817 . While the research done by Al-Ugla, et al [9], for a single absorption refrigeration system with the same working fluid ( $\mathrm{LiBr} / \mathrm{H} 2 \mathrm{O}$ ) placed in Dhahran, Saudi Arabia (latitude $=26.16^{\circ} \mathrm{N}$ ) found a $\mathrm{COP}$ value of 0.8567 . When compared with these studies, the COP results in this study are relatively lower. This is because Dhahran has a larger average daily total solar radiation energy (5.84 kWh / m2) compared to Surabaya $(5,284$ $\mathrm{kWh} / \mathrm{m} 2)$.

The solar air conditioning cooling system has a varying coefficient of performance (COP) value, depending on the type of working fluid and its composition. Here are the coefficient of performance (COP) results of these variables in graphical form: 


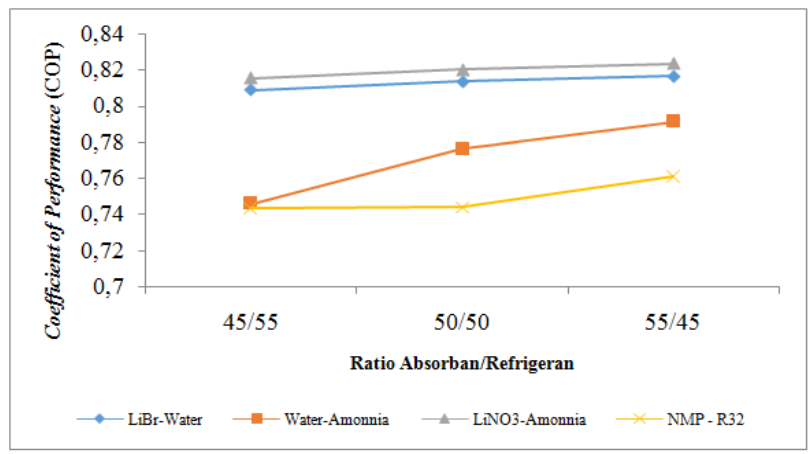

Fig. 5. Graph of COP Relation with Composition

From the graph above shows that LiNO3-H2O has a relatively higher $\mathrm{COP}$ value compared to $\mathrm{LiBr}-\mathrm{H} 2 \mathrm{O}$. In addition, the use of LiNO3-NH3 as a working fluid can also avoid the occurrence of crystallization processes that can inhibit system performance [12] and the use of $\mathrm{NH} 3$ as a refrigerant is more advantageous because it can be evaporated at lower temperatures than water [13].

In addition, from the graph above it can be concluded that for all four working fluid variables, the greater the composition of refrigerant in working fluid, the greater the coefficient of performance (COP) value of the cooling system. This is because to achieve the cooling capacity of $5000 \mathrm{Btu} /$ hour, working fluid with a small refrigerant composition will require more working fluid, so the pump and solar thermal collector load will be greater.

\section{Economic Analysis}

Economic analysis is one important factor that must be taken into account in determining whether solar air conditioning is feasible to be used or not. In the economic analysis will be analyzed the annual worth of solar air conditioning system and commercial air conditioning.

Previously it was found that based on the simulation results for solar air conditioning system that has been done found that the combination of working fluid LiNO3/NH3 with the composition of each substance 45\%: $55 \%$ has the highest Coefficient of Performance (COP) so that in this economic analysis, solar air conditioning system analysed is a system with working fluid LiNO3/NH3 with the composition ratio of each substance $45 \%$ : $55 \%$.

Next, calculate the capital cost for solar air conditioning by finding the price for each component of the equipment needed to install a solar air conditioning. The solar air conditioning system (absorption refrigeration) consists of a solar thermal collector, three heat exchanger units, two vessel units and one pump unit. Capacity for each equipment is obtained from simulation result using Aspen plus.

The price of the equipment at any time will change depending on the economic changes. If the price of a device with a certain capacity is known, then the price of equipment with other capacity can be estimated by using Chemical Engineering Plant Cost Index (CEPCI). Similarly, if the price of the tool in a given year is known, then the price of the tool in another year can be estimated [14].

$$
\begin{aligned}
\mathrm{C}_{\mathrm{E}} & =\mathrm{C}_{\mathrm{B}}\left(\frac{\mathrm{Q}}{\mathrm{Q}_{\mathrm{B}}}\right)^{0,6} \\
\frac{\mathrm{C}_{1}}{\mathrm{C}_{2}} & =\frac{\operatorname{INDEX}_{1}}{\operatorname{INDEX}_{2}}
\end{aligned}
$$

Where $\mathrm{C}_{\mathrm{E}}=$ equipment cost with capacity $\mathrm{Q}$

$\mathrm{C}_{\mathrm{B}}=$ known base cost for equipment with capacity $\mathrm{Q}_{\mathrm{B}}$

$\mathrm{C}_{1}=$ equipment cost in year 1

$\mathrm{C}_{2}=$ equipment cost in year 2

Index ${ }_{1}=$ cost index in year 1

Index ${ }_{2}=$ cost index in year 2

Based on calculations that have been done, the average capital cost for solar air conditioning with a cooling capacity of $5000 \mathrm{btu} /$ hour is as follows:

Table 5. Capital Cost for Solar Air Conditioning System

\begin{tabular}{|c|c|c|}
\hline Equipment & $\begin{array}{c}\text { Price } \\
\text { (\$) }\end{array}$ & $\begin{array}{c}\text { Price } \\
\text { (Rp.) }\end{array}$ \\
\hline Solar Thermal Collector & 456 & 6.081 .406 \\
\hline Pump & 46 & 608.095 \\
\hline Heat Exchanger 1 & 165 & 2.193 .476 \\
\hline Desorber (Storage Tank) & 245 & 3.270 .810 \\
\hline Condensor (Fan Coil) & 119 & 1.590 .387 \\
\hline Evaporator (Fan Coil) & 202 & 2.698 .297 \\
\hline Absorber (absorption chiller) & 326 & 4.347 .985 \\
\hline Accecories (pipe, insulation, etc) & 117 & 1.564 .888 \\
\hline CAPITAL COST & $\mathbf{\$ 1 . 6 7 7} *$ & Rp. 22.355.346 \\
\hline
\end{tabular}

* 1 US \$ = Rp 13.300,-

From the table above can be seen that the total investment that must be spent to install one solar air conditioning is Rp. 22.355.346. When compared with the price of vapor compression air cooler with the same cooling capacity sold in the market is about Rp. 2.950.000. It can be seen that the initial investment that must be spent to install one solar air conditioning is much larger.

After calculating the capital cost spent for the installation of a solar air conditioning and commercial air conditioner, calculated also the cost of electricity bills to be issued for each type of air conditioner, either a regular air conditioner or solar air conditioning. This is done to see how big solar air conditioning is able to save electricity energy consumption. Assume air conditioning is used every day for 10 hours per day and electricity cost is calculated for consumption for one year (30 days). Meanwhile, the basic electricity tariff used in the cost calculation is taken from State Electricity Company (PLN) tariff for household R-1/900 VA-RTM group that is Rp. $1.352 / \mathrm{kWh}$. To calculate the cost of electricity, used the formula:

Electricity Cost $=$ Usage $(\mathrm{kWh}) \times$ Basic Electricity Tariff

Based on the simulation results, it is found that commercial air-conditioning has a power of 0.4 kilowatts, equivalent to 400 watts. Based on the calculations that have been done, obtained the cost of electricity commercial air-conditioning system for 
cooling capacity of $1.465 \mathrm{~kW}$ is Rp. 5.408 , - / per day or equivalent to Rp.1.973.920, - / per year.

Meanwhile, in the same way calculated also the cost of electricity for solar air conditioning, it was found that solar air conditioning has a power of 0.0046 kilowatts or equivalent to 4.6 watts. Based on the calculation that has been done, got the cost of solar air conditioning electricity for cooling capacity of $1,465 \mathrm{~kW}$ is Rp. 62 , - / per day or equivalent to Rp.22.700, - / per year.

Based on the calculation of the cost of electricity per month to be spent for each type of air conditioner, it is found that by using solar air conditioning can save electricity costs by $98.85 \%$ compared to using commercial air conditioning. This shows that solar air conditioning is capable of efficient use of electrical energy that can impact on the cost savings of electricity bills while reducing greenhouse gas (CO2) emissions that can have adverse environmental impacts.

To compare between the two cooling systems, an annual worth (AW) analysis is used as a basis for consideration. The Annual Worth Method (AW) or also called annual equivalent is the method by which cash inflows and cash outflows are distributed in a series of annual money values evenly (equal), any period of time over the life of the investment, at a desired minimum rate of return (MARR) [14].

To perform an annual worth analysis, data on the life time of each system is required. For solar air conditioning system (absorption-refrigeration) can last up to 30 years, while commercial $\mathrm{AC}$ can last up to 10 years [6]. Therefore, the life time set for this analysis is 30 years. Here are the data used for the annual worth analysis:

Table 6. Analysis Data for Annual Worth Calculation

\begin{tabular}{|c|c|c|c|}
\hline Tipe & $\begin{array}{c}\text { Capital Cost } \\
\text { (Rp) }\end{array}$ & $\begin{array}{c}\text { Operating } \\
\text { Cost (Rp) }\end{array}$ & $\begin{array}{c}\text { Life Time } \\
\text { (year) }\end{array}$ \\
\hline $\begin{array}{c}\text { Solar Air } \\
\text { Conditioning }\end{array}$ & 22.355 .346 & 22.700 & 30 \\
\hline $\begin{array}{c}\text { Commercial Air } \\
\text { Conditioning }\end{array}$ & 2.950 .000 & 1.973 .920 & 10 \\
\hline
\end{tabular}

By setting a MARR value of $6.5 \%$ (Bank Indonesia deposit interest rate), it is found:

AW of solar air conditioning = -Rp. 1.734.615, -

AW of commercial air conditioning = -Rp. 2.384.278, -

A negative sign at the annual worth value indicates the value of expenditure to be incurred annually. In the analysis of annual worth selected system with the largest annual worth value. Of the two systems annual worth solar air conditioning is higher than the commercial airconditioning system, which means solar air conditioning system is more economically profitable.

Based on the economic analysis that has been done, it can be seen that solar air conditioning system is more economically advantageous compared with commercial air conditioner.

\section{Conclusion}

Based on the study that has been done, it can be obtained the following conclusions:

1. In terms of economic aspects, consumption of electrical energy and the impact on the environment, solar absorption is more effective than commercial cooling systems.

2. Of the four working fluids used for solar air conditioning systems, it is obtained the highest COP value is $\mathrm{LiNO}_{3}-\mathrm{NH}_{3}$ with a ratio of $45 \%$ absorbance and $55 \%$ refrigerant composition.

3. From the Coefficient of Performance (COP) analysis, $\mathrm{LiNO}_{3}-\mathrm{NH}_{3}$ can be used as a better alternative to $\mathrm{LiBr}-\mathrm{H}_{2} \mathrm{O}$ working fluid.

4. Of the four working fluids tested, it was found that the higher the composition of refrigerant in working fluid, the higher the value of Coefficient of Performance (COP) for solar air conditioning system.

\section{References}

1. Z.F. Li and K. Sumathy, Solar Energy 71, 285-297 (2001)

2. A. Syed, International Journal of Refrigeration 28, 859-871 (2005)

3. D. Zambrano, International Journal of Refrigeration 31, 315-327 (2008)

4. A. Rosario. 2014, Undergraduate Journal of Mathematical Modeling: One + Two. 6, 1, Article 1

5. F. Struckmann. Analysis of a Flat-plate Solar Collector (Project Report MVK 160 Heat and Mass Transport Sweden, 2008)

6. E. Pita. Air Conditioning Principles and Systems $4^{\text {rd }}$ ed. (Prentice Hall inc, Sadle River, N.J, 2002)

7. J.G. Ibanez. Prospect 11, 13-20 (2013)

8. C.C Allgood and C. Lawson. Performance of $R$ $438 A$ in $R-22$ Refrigeration and Air Conditioning Systems. Proceedings of the International Refrigeration and Air Conditioning Conference Purdue, July 12-15 (2010)

9. A.A. Al-Ugla, M.A.I El-Shaarawi and S.A.M. Said. International Journal of Refrigeration 53, 90-100 (2014)

10. C. Somers, Y. Hwang, R. Radermacher, P. Rodgers and S. Al-Hashimi, Applied Energy 88, 4197-4205 (2011)

11. R. Smith. Chemical Process Design and Integration (John Wiley \& Sons, Ltd, New York, 2005)

12. W. Wu, B. Wang, W. Shi, and X. Li, Hindawi Publishing Corporation Advances in Mechanical Engineering Research Article (2013)

13. J.M. Abulateef, K. Sopian, M.A. Alghoul, M.Y Sulaiman, A. Zaharim, and I. Ahmad. Solar Absorption Refrigeration System Using New Working Fluid Pairs. Proceedings of the Energy and Environment Conference UK, February 23-25 (2008)

14. M.S. Peters and K.D. Timmerhaus. Plant Design and Economics for Chemical Engineers. (Mc Graw Hill, New York, 1991) 